\title{
Prevalence of Supernumerary Teeth in Orthodontic Patients from Southwestern Brazil
}

\author{
Prevalencia de Dientes Supernumerarios en Pacientes de Ortodoncia del Suroeste de Brasi \\ Francisco Xavier Paranhos Coêlho Simões*; leda Crusoé-Rebello*; Frederico Sampaio Neves ${ }^{* * *}$; Christiano \\ Oliveira-Santos ${ }^{* *}$; Ana Lídia Ciamponi; ${ }^{* * *}$ \& Omar Gabriel da Silva Filho****
}

SIMÕES, F. X. P. C.; CRUSOÉ-REBELLO, I.; NEVES, F. S.; OLIVEIRA-SANTOS, C.; CIAMPONI, A. L. \& DA SILVA FILHO, O. G. Prevalence of supernumerary teeth in orthodontic patients from Southwestern Brazil. Int. J. Odontostomat., 5(2):199-202, 2011.

ABSTRACT: The aim of this study was to investigate the prevalence of supernumerary teeth in a Brazilian pediatric population. One examiner evaluated the presence of supernumerary teeth in panoramic radiographs of 1719 subjects (762 male and 957 female), with ages ranging from 4 to 14.5 years (mean 8.4 years old), from the archive of the Preventive Orthodontic Course of the Rehabilitation Hospital of Bauru, São Paulo. Supernumerary teeth were present in thirty subjects (1.7\%, 16 males and 14 females). Difference between sexes was not statistically significant. Twenty-nine supernumerary teeth $(96.7 \%)$ were located in the maxilla, and only $1(3.3 \%)$ located in mandible. Seventeen supernumerary teeth $(56.7 \%)$ located in maxilla were mesiodens. The early diagnosis of supernumerary teeth is essential to prevent malocclusion and malposition of permanent teeth demonstrating the importance of panoramic radiographs in their detection.

KEY WORDS: supernumerary teeth, mesiodens, dental anomalies.

\section{INTRODUCTION}

Hyperdontia or supernumerary teeth is defined as an increased number of teeth in a given individual, i.e., more than 20 teeth in deciduous dentition or 32 in permanent dentition (Leco Berrocal et al., 2007). It has been suggested that supernumerary teeth originate from the dental lamina, due to embryogenic aberrations during facial development, and by excessive proliferation of epithelial remnants of the dental lamina induced by pressure from the permanent dentition (Rajab \& Hamdan et al., 2002). Others factors like DNA mutations, including maxillofacial anomalies such as cleft lip and palate, cleidocranial dysplasia and Gardner's syndrome may give rise to supernumerary teeth (De Oliveira Gomes et al., 2008).

Supernumerary teeth may cause different local disorders, including retention of primary teeth and delayed eruption of permanent teeth, ectopic eruptions, teeth displacement and follicular cysts, among other alterations requiring surgical or orthodontic intervention (Leco Berrocal et al.).

Panoramic radiographs are largely used as an important diagnostic tool in dental practice. Dental and bony injuries, presence of cysts and tumors, and dental anomalies of number, size and shape, are examples of alterations that can be conveniently observed on a panoramic radiograph. The use of panoramic radiographs to identify developmental disturbances in children around the ages of 6 to 9 years has been indicated (Cholitgul \& Drummond, 2000).

Early detection of dental development anomalies is very important. Such conditions are frequently observed in orthodontic patients, and may complicate the orthodontic treatment planning (Locht, 1980; Vichi \& Franchi, 1995; Garvey et al., 1999). There have been several studies investigating the prevalence of dental

\footnotetext{
Department of Pediatric Dentistry, Bahiana Foundation for the Development Sciences, School of Dentistry, Brazil.

** Department of Oral Radiology, Federal University of Bahia, School of Dentistry, Brazil.

*** Department of Oral Diagnosis, State University of Campinas, Piracicaba Dental School, Brazil.

**** Department of Orthodontic and Pediatric Dentistry, University of São Paulo, Brazil.

-*n+* Department of Orthodontic, University of São Paulo, Bauru School of Dentistry, Brazil.
} 
SIMÕES, F. X. P. C.; CRUSOÉ-REBELLO, I.; NEVES, F. S.; OLIVEIRA-SANTOS, C.; CIAMPONI, A. L. \& DA SILVA FILHO, O. G. Prevalence of supernumerary teeth in orthodontic patients from Southwestern Brazil. Int. J. Odontostomat., 5(2):199-202, 2011.

abnormalities, however few have been conducted on orthodontic patients (Cholitgul \& Drummond; Locht; Thongudomporn \& Freer, 1998). Supernumerary teeth and dental agenesis are the most common developmental abnormalities founded in children. Supernumerary teeth may be impacted, but eventually some may be found erupted in the mouth. They may present as single or multiple extra teeth, unilateral or bilateral, in maxilla, mandible or both (Vichi \& Franchi; Garvey et al.).

The aim of this study was to investigate the prevalence of supernumerary teeth in orthodontic records of a Southwestern Brazilian pediatric population.

\section{MATERIAL AND METHOD}

Panoramic radiographs of 1719 orthodontic patients (762 male and 957 female) from the archive of the Preventive Orthodontic Course of the Rehabilitation Hospital of Bauru, São Paulo were evaluated for presence of supernumerary teeth. The mean age of the patients was 8.4 years (range 4 years and 4 months to 14 years and 6 months) at the time the radiographs were taken. All panoramic radiographs were taken at the same Radiology Center using the same machine. Exclusion criteria included: history of dental trauma, and/or tooth extraction prior to orthodontic treatment.

All the panoramic radiographs were examined by one observer, in a dimly lit room with a black mask attached to the view box. The findings on the panoramic radiographs were registered, and statistical analysis of the data was performed using the chi-square or Fischer tests.

\section{RESULTS}

Supernumerary teeth were found in thirty subjects $(1.7 \%)$, of which sixteen were male $(0.9 \%)$ and fourteen female $(0.8 \%)$. The difference among sexes was not statistically significant (Table I).

Among the thirty patients with this dental anomaly, twenty-four (80\%) presented one supernumerary tooth, while six $(20 \%)$ had two extra teeth. No differences among sexes for number of supernumerary was found (Table I). The presence of more than two supernumerary teeth per patient was not found.

Twenty-nine supernumerary teeth $(96.7 \%)$ were located in the maxilla, whilst only one (3.3\%) was located in mandible. Seventeen supernumerary teeth $(56.7 \%)$ located in maxilla were mesiodens i.e. supernumerary teeth located near the midline in the maxilla (Table II).

Table II. Frequency of supernumerary teeth according to maxilla or mandible.

\begin{tabular}{lcc}
\hline & Maxilla n (\%) & Mandible n (\%) \\
\hline Frequency & $29(96.7 \%)$ & $1(3.3 \%)$ \\
Mesiodens & $17(56.7 \%)$ & $0(0 \%)$ \\
\hline
\end{tabular}

\section{DISCUSSION}

Genetics normally determines formation of thirtytwo teeth to compose normal human permanent denture. However, developmental dental abnormalities, such as anomalies of number, shape and size of teeth may affect patients even without genetic syndromes. This vulnerability in the permanent denture confirms the importance of panoramic radiographs as a routine diagnostic method previous to orthodontic treatment.

Supernumerary teeth, or hyperdontia, may manifest in any region of the dental arches. Multiple supernumerary teeth that are not related to any syndrome are very rare; in these individuals supernumerary teeth are frequently found in the premolar area (Açikgoz et al., 2006). Multiple hyperdontia can be associated with Gardner syndrome,

Table I. Frequencies of number of supernumerary teeth according to sex.

\begin{tabular}{lcrr}
\hline & Male (\%) & Female (\%) & \multicolumn{1}{c}{ Total (\%) } \\
\hline One supernumerary teeth & $12(75 \%)$ & $12(87.5 \%)$ & $24(80 \%)^{*}$ \\
Two supernumerary teeth & $4(25.5 \%)$ & $2(14.3 \%)$ & $6(20 \%)^{*}$ \\
Total & $16(53.3 \%)$ & $14(46.7 \%)$ & $30(100 \%)$ \\
\hline
\end{tabular}

*no-significant between sexes $(p>0.05)$ by Fisher test. 
Fabry-Ander-son syndrome, Ehlers-Danlos syndrome, facial fistulas or cleidocranial dysplasia (Montenegro et al., 2006). The detection of supernumerary teeth can be an important feature in the diagnosis of these conditions.

There are few studies investigating the prevalence of supernumerary in orthodontic patients (Cholitgul \& Drummond; Locht; Thongudomporn \& Freer). Our results showed a prevalence rate $(1.74 \%)$ similar to those found by other Brazilian studies - 1.2\% (Campos, 1996), 1.41\% (Primo et al., 1997), 1.1\% (Lee, 1999), 1.5\% (Girondi et al., 2006). However, other studies have found much higher $-7.38 \%$ (Tanaka et al., 1995) and $2.5 \%$ (Côrrea et al., 2009), and lower prevalence rates $-0.3 \%$ (Kramer et al., 2008).

In most of the previous studies, males are affected twice as much as females (Bondin et al., 1978; Liu, 1995; Humerfelt et al., 1985). In our study, males were more affected than females, but the difference was not statistically significant.

Supernumerary teeth may present as an isolated extra tooth or as multiple teeth, in any region of the mandible or maxilla. However, the most frequent location of the supernumerary teeth is in the maxilla, mainly in anterior region. More rarely, they can be located in the upper molar, lower premolar, upper premolar, lower molar, upper canine and inferior incisor (Leco Berrocal et al.; Ferrés-Padró et al., 2009). They may have different forms, ranging from similar to a normal tooth to conoid, supplemental, or mixed morphologies. In agreement with previous studies (Leco Berrocal et al.; Rajab \& Hamdan; Vichi \& Franchi; Açikgoz et al.; Gündüz et al., 2008), most supernumerary teeth were found in the anterior maxilla region (mesiodens). Seventeen mesiodens were observed in the maxilla, whilst none were found in the mandible. The shape of mesiodens can be conical and canine-like, or more rarely incisor-like, tuberculated and round. The most common position of mesiodens are vertical or inverted (Gündüz et al.).

In some cases, supernumerary teeth can be associated to odontomas, causing its impaction. This association frequently occurs in the anterior maxilla region (Esenlik et al., 2009).

Clinical complications are not uncommon in patients with supernumerary teeth. Tooth displacement and failure of eruption are the most frequent complications. Other studies have shown that tooth displacement is a clinical complication frequently observed, however, cyst formation, root anomalies, and intraoral infections may also be observed (Gündüz et al.). Moreover, a possible relationship between supernumerary teeth and other developmental anomalies, such as talon cusps and dens evaginatus, has been proposed (Cho, 2005; Lee et al., 2007).

Most supernumerary teeth are impacted and asymptomatic and diagnosed incidentally on radiographic examinations. Panoramic radiograph is thus essential for the early detection of supernumerary teeth, among many other dental and bone conditions that might influence orthodontic treatment outcome.

SIMÕES, F. X. P. C.; CRUSOÉ-REBELLO, I.; NEVES, F. S.; OLIVEIRA-SANTOS, C.; CIAMPONI, A. L. \& DA SILVA FILHO, O. G. Prevalencia de dientes supernumerarios en pacientes de ortodoncia del suroeste de Brasil. Int. J. Odontostomat., 5(2):199-202, 2011.

RESUMEN: El objetivo de este estudio fue investigar la prevalencia de dientes supernumerarios en una población pediátrica de Brasil. Un examinador evaluó la presencia de dientes supernumerarios en radiografías panorámicas de 1719 sujetos (762 hombres y 957 mujeres), con edades comprendidas entre 4 y 14,5 años (media 8,4 años de edad), del archivo del Curso de Ortodoncia Preventiva del Hospital de Rehabilitación de Bauru, São Paulo. Los dientes supernumerarios se presentaron en treinta sujetos $(1,7 \%, 16$ hombres y 14 mujeres). La diferencia entre sexos no fue estadísticamente significativa. Veintinueve dientes supernumerarios $(96,7 \%)$ se ubicaron en el maxilar, y sólo 1 (3,3\%) se ubicó en la mandíbula. Diecisiete dientes supernumerarios $(56,7 \%)$ ubicados en el maxilar eran mesiodens. El diagnóstico precoz de los dientes supernumerarios es esencial para prevenir la maloclusión y malposición de los dientes permanentes, lo que demuestra la importancia de la radiografía panorámica en su detección.

PALABRAS CLAVE: dientes supernumerarios, mesiodens, anomalías dentales.

\section{REFERENCES}

Açikgoz, A.; Açikgoz, G.; Tunga, U. \& Otan, F. Characteristics and prevalence of non-syndromic multiple supernumerary teeth: a retrospective study. Dentomaxillofac. Radiol., 35(3):185-90, 2006. 
SIMÕES, F. X. P. C.; CRUSOÉ-REBELLO, I.; NEVES, F. S.; OLIVEIRA-SANTOS, C.; CIAMPONI, A. L. \& DA SILVA FILHO, O. G. Prevalence of supernumerary teeth in orthodontic patients from Southwestern Brazil. Int. J. Odontostomat., 5(2):199-202, 2011.

Bodin, I.; Julin, P. \& Thomsson, M. Hyperodontia. I. Frequency and distribution of supernumerary teeth among 21.609 patients. Dentomaxillofac. Radiol., 7(1):15-7, 1978.

Campos, P. S. F. Estudo da prevalência de anomalias dentárias de desenvolvimento, através do exame radiográfico panorâmico, numa amostra populacional da cidade de Salvador. Dissertação (Mestrado), Salvador, Faculdade de Odontologia da Universidade Federal da Bahia, 1996.

Cho, S. Y. Supernumerary premolars associated with dens evaginatus: report of 2 cases. J. Can. Dent. Assoc., 71(6): 390-3, 2005.

Cholitgul, W. \& Drummond, B. K. Jaw and tooth abnormalities detected on panoramic radiographs in New Zealand children aged 10-15 years. N. Z. Dent. J., 96(423):10-3, 2000.

Corrêa, F. G.; Ferreira, F. V.; Roggia, L. F.; Pistóia, A. D. \& Pistóia, G. D. Prevalência de dentes supranumerários estudo retrospectivo. Int. J. Dent., 8(1):11-5, 2009.

De Oliveira Gomes, C.; Drummond, S. N.; Jham, B. C.; Abdo, E. N. \& Mesquita, R. A. A survey of 460 supernumerary teeth in Brazilian children and adolescents. Int. J. Paediatr. Dent., 18(2):98-106, 2008.

Esenlik, E.; Sayin, M. O.; Atilla, A. O.; Ozen, T.; Altun, C. \& Bas,ak, F. Supernumerary teeth in a Turkish population. Am. J. Orthod. Dentofacial. Orthop., 136(6):848-52, 2009.

Ferrés-Padró, E.; Prats-Armengol, J. \& Ferrés-Amat, E. A descriptive study of 113 supernumerary teeth in 79 pediatric patients in Barcelona. Med. Oral Patol. Cir. Bucal., 14(3):146-52, 2009.

Garvey, M. T.; Barry, H. J. \& Blake, M. Supernumerary teeth-an overview of classification, diagnosis and management. J. Can. Dent. Assoc.,65(11):612-6, 1999.

Girondi, J. R.; Fenyo-Pereira, M.; Campos, P. S. F. \& Panella, J. Estudo da prevalência das anomalias dentárias de desenvolvimento em dada população, com o uso de radiografias panorâmicas. Rev. Odontol. Univ. Cid. Sao Paulo, 18(1):15-21, 2006.

Gündüz, K.; Celenk, P.; Zengin, Z. \& Sümer, P. Mesiodens: a radiographic study in children. J. Oral. Sci., 50(3):287-91, 2008.

Humerfelt, D.; Hurlen, B. \& Humerfelt, S. Hyperdontia in children below four years of age: a radiographic study. ASDC J. Dent. Child.,52(2):121-4, 1985.

Kramer, P. F.; Feldens, C. A.; Ferreira, S. H.; Spiguel, M. H. \& Feldens E. G. Dental anomalies and associated factors in 2- to 5-year-old Brazilian children. Int. J. Paediatr. Dent., 18(6):434-40, 2008.
Leco Berrocal, M. I.; Martín Morales, J. F. \& Martínez González, J. M. An observational study of the frequency of supernumerary teeth in a population of 2000 patients. Med. Oral Patol. Cir. Bucal, 12(2):E134-8, 2007.

Lee, K. B. Estudo da prevalência de anomalias dentárias de desenvolvimento através de radiografias panorâmicas, numa amostra populacional da cidade de São Paulo. Dissertação (Mestrado). São Paulo, Faculdade de Odontologia da Universidade de São Paulo, 1999.

Lee, C. K.; King, N. M.; Lo, E. C. \& Cho, S. Y. The relationship between a primary maxillary incisor with a talon cusp and the permanent successor: a study of 57 cases. Int. J. Paediatr. Dent., 17(3):178-85, 2007.

Liu, J. F. Characteristics of premaxillary supernumerary teeth: a survey of 112 cases. ASDC J. Dent. Child., 62(4):262-5, 1995.

Locht, S. Panoramic radiographic examination of 704 Danish children aged $9--10$ years. Community Dent. Oral Epidemiol., 8(7):375-80, 1980.

Montenegro, P. F.; Castellón, E. V.; Aytés, L. B. \& Escoda, C. G. Retrospective study of 145 supernumerary teeth. Med. Oral Patol. Oral Cir. Bucal., 11(4):39-44, 2006.

Primo, L. G.; Wilhelm, R. S. \& Bastos, E. P. S. Frequency and characteristics of supernumerary teeth in Brazilian children: consequences and proposed treatments. Rev. Odontol. Univ. São Paulo, 11(4):231-7, 1997.

Rajab, L. D. \& Hamdan, M. A. Supernumerary teeth: review of the literature and a survey of 152 cases. Int. J. Paediatr. Dent., 12(4):244-54, 2002.

Tanaka, E. E.; Arita, E. S.; Ferreira, E. T. T. \& Varoli, O. J. Prevalências das anomalias dentárias em LondrinaParaná. RPG Rev. Pós Grad., 2(3):132-7, 1995.

Thongudomporn, U. \& Freer, T. J. Prevalence of dental anomalies in orthodontic patients. Aust. Dent. J., 43(6):3958, 1998.

Vichi, M. \& Franchi, L. Abnormalities of the maxillary incisors in children with cleft lip and palate. ASDC J. Dent. Child., 62(6):412-7, 1995.

Correspondence to:

lêda Crusoé-Rebello

Federal University of Bahia

Department of Oral Radiology

Av. Araújo Pinho, 62, CEP 40110-150

Salvador, Bahia

BRAZIL

Email: iarebello@ig.com.br

Received: 04-01-2011 Accepted: 07-06-2011 